REFLECTIONS:

NEUROLOGY AND

THE HUMANITIES

Section Editor

Anne W. McCammon,

MD, FAAN

\title{
IEDs
}

\section{A concussion and a photo dilemma}

"Nice picture, Gunny," I said as I handed the photo back to the gunnery sergeant. I recognized immediately that my objectivity had just been compromised. I knew better than to look at some of the photos thrust at me by the soldiers, marines, and sailors that I encountered as patients. Far too often, those photos were trophies. The enemy may have hurt us, but look at what we did to him. What were they thinking? Photos like that can later haunt their possessor.

This particular marine was one of about 200 service members that I evaluated for concussion symptoms after exposure to the blast wave associated with an improvised explosive device (IED). Those who were not killed or visibly injured by IEDs often found their way to be assessed at the combat support hospital that I commanded. The 2 to 3 weeks typically spent in Kuwait allowed time for their acute symptoms to resolve or subside before being returned to duty in Iraq.

Even though these service members had avoided the heat and shrapnel injuries associated with an IED, they had still been struck by the wave of compressed air traveling at hundreds of feet per second. That blast wave was like being struck by a "brick wall" of air, and most had been knocked down and knocked out. They invariably complained of headache, trouble hearing, tinnitus, poor balance, and difficulty concentrating. Moreover, most of them were simultaneously frightened and angry. Someone had just deliberately tried to kill them. Now they wanted to kill someone in return.

Our routine in handling these IED concussion victims was pragmatic. Once they arrived at the combat support hospital, they were assessed in casualty receiving and a head CT scan would be obtained. Those scans were uniformly unrevealing. My hospital did not have an assigned neurologist, but since I was a neurologist, I would examine and evaluate each of these concussion patients. Their neurologic examinations were also similarly unremarkable. I would then order a brain MRI to be performed 10-14 days later in Kuwait City to make sure that they had not sustained a traumatic brain injury that could not be detected on head CT.
During the next 2 weeks, these service members would be required to attend regular psychiatric counseling sessions aimed at recognizing, coping with, and ameliorating the symptoms of posttraumatic stress disorder. In essence, we were forcing them to cool their heels while time and boredom were utilized as therapeutic adjuvants.

By the time that I saw them 1 week after their concussion, their symptoms were already improving. By 2 weeks after their concussion, virtually all readily acknowledged their concussive symptoms had resolved. Their overt anger had also subsided. Most were bored and eager to get the hell out of Kuwait and be returned to their units, to be with their comrades and to get on with their mission.

This marine gunnery sergeant was unique. As it turned out, he was the only individual that I evaluated with concussion symptoms from an IED blast that I did not return to duty in Iraq. I have always wondered whether the photo the Gunny shared with me unduly affected my judgment and my decision.

Like me, the Gunny was a reservist. In civilian life, he was a homicide detective in a large American city police force. In Iraq, he was a member of a military police unit that was training Iraqi police recruits and police officers. Of the 16 original members of his unit, 4 had already been killed by IEDs. The primary objective of those IEDs was to discourage Iraqis from working with and collaborating with the American "occupiers." Moreover, this had been the Gunny's third concussion from an IED blast during his current tour of duty, and he had only 2 more months remaining in his current deployment. $\mathrm{He}$ readily recognized and acknowledged that his acute concussion symptoms would soon abate. Although I could not detect any definite abnormalities with my crude bedside neuropsychological testing, the Gunny complained that his thinking was not fully coherent. He was concerned that his multiple concussions would adversely impact his ability to be an effective homicide detective when he returned home. He made no obvious or overt attempt to feign, embellish, or magnify any of his symptoms.

Listen to Dr. Riggs read this story, available exclusively on Neurology ${ }^{\circledR}$ for the iPad ${ }^{\circledR}$

Any assertions and opinions, explicit or implicit, are those of the author and should not be construed to represent those of the United States Navy or the United States Marine Corps. 
The Gunny was obviously bright and observant. He told me that he recognized that the embroidered trident patch above my name tag identified me as the hospital commanding officer. Was I being played?

As a senior medical leader, I had been thoroughly indoctrinated in the role of military medicine. My primary mission was to conserve the fighting force. Of course, I was to render any and all available aid to those injured in war, but I was not to abuse the special deference and trust given to military medicine to personally decide who participated in war. All service members, especially in today's all-volunteer force, had given their explicit consent to being placed in harm's way and becoming legitimate enemy targets. Consequently, if fate or bad luck placed a soldier, marine, sailor, or airman in harm's way, then so be it. If military health care providers were to decide to "protect" or "save" an individual service member from war, we would just be arbitrarily placing someone else in harm's way.

I was going to have to make a decision that I did not particularly want to make. And I could not get the Gunny's photo out of my mind. As expected, his brain MRI came back normal. There would be no easy out for me. I discussed this case with my longtime friend and Director of Clinical Services. I described to him this 35-year-old marine who had sustained multiple concussions from IED blasts, his complaints of difficulty with executive cognitive functioning, his intact bedside neurological examination, and his normal imaging studies. I could return this marine to duty in Iraq, where he would certainly be at risk of additional concussions and perhaps permanent cognitive impairment, or I could medevac him out of theater for formal neuropsychological testing. I did not tell my director about the Gunny's photo. If I was expecting help with my decision from my friend, I did not get it.

"Skipper, you don't have to justify any decision you make to me. You just tell me what you want, and I will see to it that it happens," was his response.

There was no more delaying my decision.

"Send him home. Have him sent via Germany back to Bethesda for formal neuropsychological testing for possible cognitive dysfunction caused by multiple concussions from IED blasts. I don't want him to be evaluated in Germany by someone who could second-guess and reverse my decision," I responded. No matter what Bethesda decided, with only 2 months remaining on his deployment, there would not be enough time for the Gunny to be returned to Iraq.

The following day, I told this marine the results of his brain MRI and informed him that I was sending him to Bethesda. If I had expected him to protest that decision, or was hoping that he would, he did not.

"Thank you, Captain," was his only response.

"You are welcome, Gunnery Sergeant," I replied, firmly shaking his hand. "And thank you for your service to your country," I added.

I had previously chastised my nurses for trying to save a soldier from war, and now here I was doing the same thing. I had previously scolded a foreign military medical officer for not thinking and acting like a military physician, and now here I was doing the same thing. Albeit in a different context, my current action was not congruous with my previous words. My Director of Clinical Services recognized those contradictions, but he did not rub those discrepancies in my face. I think he just assumed that I had my reasons, and that was good enough for him.

I never doubted that I could medically justify my decision to send the Gunny out of theater. What neurologist under normal circumstance would require that his or her patient, who had recently sustained 3 significant concussions performing a certain activity, continue that activity? The real issue was whether I could justify that decision to myself. Had I unjustly made some other individual, unknown to me, assume the Gunny's risk? To be clear, at this stage in my military career and at this point in my deployment, I was hardened to the cruel realities of war. Whether the Gunny survived his deployment or whether he could effectively function as a homicide detective once he got home could not influence my decision. The Gunny knew the risks and had consented to take those risks. From my perspective, I had already witnessed many other service members whose lives were lost or shattered far beyond any sacrifice that the Gunny had made.

My conscience had to deal with the photo that the Gunny showed me and whether that photo unduly interfered with my judgment. It was a family picture showing 5 smiling faces: the Gunny in civilian clothes, his wife, and 3 adorable daughters who appeared to range in age from 3 to 7 years. Those little girls had never consented to any of this, and they certainly had not consented to possibly losing their dad in a war that many grownups had difficulty understanding or explaining.

The fact that I still ponder all this makes me think that I may have made the wrong decision. When I find myself thinking that way, I gain temporary relief by reminding myself that sometimes in life you find yourself in inhumane situations wherein you must make some decision with a brain entangled with human emotions. 


\title{
Neurology
}

\author{
IEDs: A concussion and a photo dilemma \\ Jack E. Riggs \\ Neurology 2015;84;e85-e86 \\ DOI 10.1212/WNL.0000000000001400
}

This information is current as of March 23, 2015

\section{Updated Information \& Services}

Subspecialty Collections

Permissions \& Licensing

\section{Reprints}

including high resolution figures, can be found at: http://n.neurology.org/content/84/12/e85.full

This article, along with others on similar topics, appears in the following collection(s):

All Clinical Neurology

http://n.neurology.org/cgi/collection/all_clinical_neurology

All Ethics in Neurology/Legal issues

http://n.neurology.org/cgi/collection/all_ethics_in_neurology_legal_iss ues

All Trauma

http://n.neurology.org/cgi/collection/all_trauma

Information about reproducing this article in parts (figures,tables) or in its entirety can be found online at:

http://www.neurology.org/about/about_the_journal\#permissions

Information about ordering reprints can be found online:

http://n.neurology.org/subscribers/advertise

Neurology $®$ is the official journal of the American Academy of Neurology. Published continuously since 1951 , it is now a weekly with 48 issues per year. Copyright @ 2015 American Academy of Neurology. All rights reserved. Print ISSN: 0028-3878. Online ISSN: 1526-632X.

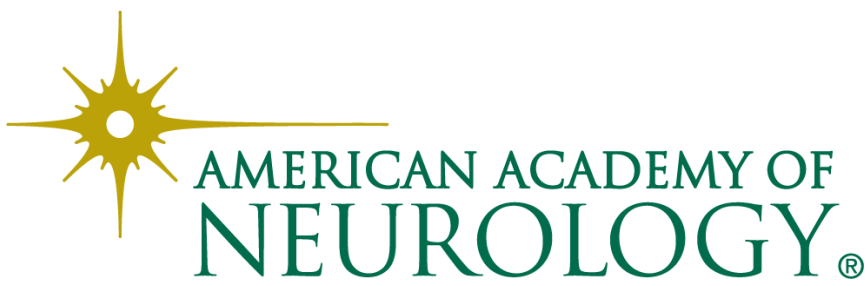

